\title{
ПОРІВНЯЛЬНИЙ АНАЛІЗ МОДЕЛЕЙ ІПОТЕЧНОГО РЕФІНАНСУВАННЯ
}

\author{
Національний університет біоресурсів \\ і природокористування України, \\ Міністерство освіти і науки України, \\ кафедра туристичного та готельно- \\ ресторанного бізнесу і консалтингу, \\ вул. Героїв Оборони, 11, м. Київ, \\ 03041, Україна, \\ тел. +380673015151 , \\ e-mail: devenezia@gmail.com
}

\begin{abstract}
Анотація. В складній фінансово-економічній та політичній ситуації, збій кредитної системи безумовно може стати причиною банківської кризи, що вже неодноразово траплялось в історії України. Проблеми з ліквідністю та платоспроможністю банківських кредитних установ у такій ситуації може вирішити НБУ як кредитора останньої інстанції, який здійснює підтримку банків шляхом рефінансування. Однак кризові явища у вітчизняній банківській системі спонукають по-новому розглядати рефінансування банків, що стимулює до пошуків його ефективних інструментів та механізмів, зокрема до іпотечного рефінансування. Досвід фінансових криз показу, що саме моделі іпотечного рефінансування потребують подальшого ретельного дослідження, адже вони перш за все пов'язані із ризиками, притаманними тій чи іншій моделі. Метою статті є порівняльний аналіз різних моделей іпотечного рефінансування, оцінка притаманних їм ризиків та дослідження розподілу цих ризиків між учасниками іпотечного кредитування та рефінансування.

Методологічною основою проведеного дослідження $є$ загальнонаукові та спеціальні методи пізнання, дослідно-пошукова література, наукові праці вітчизняних вчених з питань рефінансування, іпотечного рефінансування, особливо в умовах кризи, а також інші методи, такі як системний аналіз; синтез, статистичний метод та інші.

У світовій практиці є три основні моделі іпотечного рефінансування, кожна 3 яких поряд зі спільними для всіх моделей рисами, має специфічні, притаманні лише їй ознаки. Найдавнішою i, мабуть, найнадійнішою є так звана однорівнева, модель, поширена в європейських та багатьох інших країнах світу. Дворівневі моделі, поширені у США та деяких азійських країнах, а також, до певної міри, у Франції, є мобільнішими порівняно з першою, але й більш ризиковими. Дослідження ризиків, пов’язаних із функціонуванням тієї чи іншої моделі, $€$ дуже актуальним, а тому заслуговує на значну увагу науковців та практиків.

Наукова новизна полягає в проведеному порівняльному аналізі моделей іпотечного рефінансування та їх зв’язку із фінансовими кризами. Запропоновано створення механізму іпотеки, який поєднує паралельне співіснування двох моделей (одно- та дворівневої) функціонування ринку іпотечного кредитування.

Практична значимість статті полягає в розв'язані дилеми: як ефективно і безпечно для всіх учасників кредитного ринку використати надані можливості моделей рефінансування в умовах фінансово-економічної кризи.
\end{abstract}

Ключові слова: рефінансування; іпотечне рефінансування; моделі іпотечного рефінансування; національний регулятор; кредитні ризики, банківська криза.

\section{THE COMPARATIVE ANALYSIS OF MORTGAGE REFINANCING MODELS}

The National University of Life and Environmental Sciences of Ukraine, Ministry of Education and Science of Ukraine, 


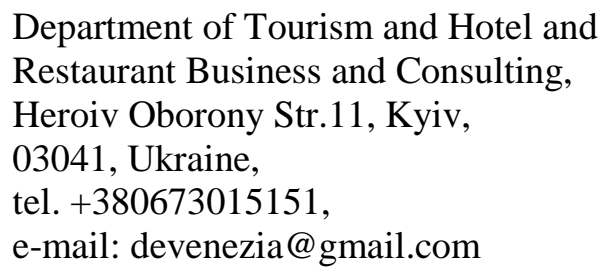

\begin{abstract}
In a difficult financial, economic and political situation, the failure of the credit system can certainly cause a banking crisis, which has repeatedly happened in the history of Ukraine. Problems with liquidity and solvency of bank credit institutions in this situation can be solved by the NBU as a lender of last resort, which provides support to banks through refinancing. However, the crisis in the domestic banking system encourages a new consideration of bank refinancing, which encourages the search for its effective tools and mechanisms, including mortgage refinancing. The experience of financial crises has shown that mortgage refinancing models need further careful study, as they are primarily related to the risks inherent in a particular model. The purpose of the article is a comparative analysis of different models of mortgage refinancing, assessment of their inherent risks and study of the distribution of these risks between the participants of mortgage lending and refinancing.
\end{abstract}

The methodological basis of the study are general and special methods of cognition, research literature, scientific works of domestic scientists on refinancing, mortgage refinancing, especially in times of crisis, as well as other methods such as systems analysis; synthesis, statistical method and others.

In world practice, there are three main models of mortgage refinancing, each of which, along with common features for all models, has specific, unique features. The oldest and probably the most reliable is the so-called single-level model, common in European and many other countries. Two-tier models, common in the United States and some Asian countries, and, to some extent, in France, are more mobile than the first, but also more risky. The study of the risks associated with the operation of a particular model is very relevant and therefore deserves considerable attention from scientists and practitioners.

The scientific novelty lies in the comparative analysis of mortgage refinancing models and their relationship with financial crises. It is proposed to create a mortgage mechanism that combines the parallel coexistence of two models (one- and two-level) functioning of the mortgage lending market.

The practical significance of the article lies in the solved dilemmas: how to effectively and safely for all participants in the credit market to use the opportunities provided by refinancing models in the financial and economic crisis.

Key words: refinancing; mortgage refinancing; mortgage refinancing models; national regulator; credit risks, banking crisis.

Вступ. В сучасних економічних умовах, функціонування вітчизняної кредитної системи значно порушено, що є наслідком світової фінансово-економічної кризи 2008 року, від якої фінансова система не оговталась, а вже наступили події 2014 р., та пандемії COVID-19. В складній фінансово-економічній та політичній ситуації, збій кредитної системи безумовно може стати причиною банківської кризи, що вже неодноразово траплялось в історії України. Проблеми 3 ліквідністю та платоспроможністю банківських кредитних установ у такій ситуації може вирішити НБУ як кредитора останньої інстанції, який здійснює підтримку банків шляхом рефінансування.

Рефінансуванню банків присвячені роботи А. Ковалюка [1], У. Ніконенко, С. Реверчука [1], які зробили значний вклад у розкриття сутності рефінансування; С. Лобозинської, В. Міщенко, М. Савлука, А. Сомика, А. Шаповалова, які займались аналізом інструментів рефінансування та вдосконаленню його механізмів; Д. Гриньківа, який досліджує сучасний стан рефінансування в Україні. Особлива увага іпотечному рефінансуванню приділяється у роботах Т. Гордіци [5], Н. Грищук [6], Д. 
Актуальні проблеми розвитку економіки регіону. Вип 16. T.2

Даймонда, О. Євтуха, В. Кравченка, К. Паливоди, К. Фоллака, О. Штекера та інших. Вони виявили основні риси кожної моделі, розкрили їх зміст та характер взаємодії між учасниками іпотечного кредитування та рефінансування.

Однак кризові явища у вітчизняній банківській системі спонукають по-новому розглядати рефінансування банків, що стимулює до пошуків його ефективних інструментів та механізмів. Окрім того, багато питань, пов'язаних 3 іпотечним рефінансуванням, як показує досвід фінансових криз, потребують подальших досліджень, адже вищесказане перш за все стосується ризиків, притаманних тій чи іншій моделі.

Постановка завдання. Метою статті $є$ порівняльний аналіз різних моделей іпотечного рефінансування, оцінка притаманних їм ризиків та дослідження розподілу цих ризиків між учасниками іпотечного кредитування та рефінансування.

Результати. В теорії фінансів надається наступне визначення рефінансування: це повне або часткове погашення боргових зобов'язань за рахунок отримання нових кредитів (які зазвичай беруться під меншу процентну ставку) або за допомогою випуску нових цінних паперів для погашення боргових цінних паперів, термін по виплатах яких наступає [1, с. 42].

В широкому розумінні рефінансування - це заходи спрямовані на здешевлення позикових коштів, а також зміни умов отриманих кредитів, графіку їх погашень, процентних ставок, надання додаткових траншів [2].

В монографії «Управління реструктуризацією фінансових посередників в економіці України» [1, с. 42] зазначається, що рефінансування - $є$ важливим зовнішнім методом фінансової реструктуризації банку, суть якого полягає в методах фінансового регулювання, зокрема фінансуванні, підтримці ліквідності та кредитуванні.

Якщо звернутись до вітчизняного законодавства, то рефінансування - це операції 3 надання банкам кредитів у встановленому НБУ порядку. При цьому НБУ виконує функції кредитора останньої інстанції. А основною метою рефінансування $\epsilon$ регулювання ліквідності банківських установ. суть [3]:

3 огляду на вищезазначене, можна стверджувати, що рефінансування має трояку

1) засіб підтримки ліквідності банківських установ;

2) засіб стабілізації та вирівнювання ситуації в банках, які системно зазнають нестачі ресурсів;

3) фінансова реструктуризація банку, його боргів, тобто реструктуризація пасивів.

В умовах кризи 2008 р. був виданий Указ президента №1046 від 17.11.2008p. «Про додаткові заходи щодо подолання фінансової кризи в Україні», який пропонував НБУ запровадити цільове рефінансування банків для кредитування терміном на 5 років інвестиційних проектів під облікову ставку НБУ під заставу пулів іпотечних кредитів, у першу чергу для завершення будівництва визначених з готовністю понад 50\%; а також кредитування інфраструктурних проектів у сфері енергетики, транспорту, зв'язку [4]. Проте в умовах кризи, коли існує гостра проблема ліквідності та платоспроможності банків, довгострокове рефінансування $є$ не доцільним, тому НБУ у 2008 р. не зміг виконати вищезгадані пропозиції [3].

Система іпотечного кредитування займає унікальне місце в національній економіці. По-перше, сьогодні іпотечне кредитування в більшості економічно розвинених країн не тільки $є$ основною формою поліпшення житлових умов, вплив його відчувається на економічній ситуації країні в цілому. 3 іншого боку, система іпотечного кредитування являє собою багатоступеневий механізм, що складається із взаємозалежних підсистем і визначається тим, що він є одним із найбільш перевірених у світовій практиці надійним засобом залучення позабюджетних інвестицій у житлову 
Актуальні проблеми розвитку економіки регіону. Вип 16. T.2

сферу. Крім цього, підтримка державою розвитку іпотечного кредитування є однією 3 основних передумов досягнення реального економічного зростання у країні [5].

Відповідно до Закону України «Про іпотеку» іпотекою визначається вид забезпечення виконання зобов'язання нерухомим майном, що залишається у володінні і користуванні іпотекодавця. Іпотекотримач має право, в разі невиконання боржником забезпеченого іпотекою зобов'язання, одержати задоволення своїх вимог за рахунок предмета іпотеки переважно перед іншими кредиторами цього боржника у порядку, встановленому Законом [6]. Таким чином, виділення застави нерухомості в окрему категорію, що одержала назву «іпотека», обумовлено особливостями нерухомої власності.

Переваги іпотеки полягають не лише у надійному забезпечені зобов'язань боржників. Сек'юритизація права вимоги на обтяжене іпотекою майно дає змогу трансформувати цей низьколіквідний актив у високоліквідні цінні папери, які $\epsilon$ ефективними інструментами залучення інвестиційних потоків у сфері іпотечного кредитування. Цей процес називається іпотечним рефінансуванням.

Іпотечне рефінансування, як відомо, здійснюється за різними моделями. Найдавнішою і найпоширенішою у світі $є$ так звана однорівнева, або перша, модель. Ця модель передбачає, що випуск і розміщення іпотечних цінних паперів здійснюється тими самими установами, які надають іпотечні кредити; як правило, такими установами $€$ іпотечні банки.

Надання роздрібних іпотечних кредитів називають також первинним іпотечним ринком, а випуск та розміщення іпотечних цінних паперів - вторинним. Таким чином, за однорівневої моделі іпотечні банки оперують на первинному і на вторинному іпотечних ринках.

Іпотечні банки надають кредити позичальникам (фізичним та юридичним особам) під заставу нерухомого майна. На підставі права вимоги на обтяжене іпотекою нерухоме майно банки випускають і розміщують іпотечні цінні папери (ІЦП), залучаючи в такий спосіб кредитні ресурси і знову надають кредити під заставу нерухомості. Позичальники виконують свої зобов'язання перед банками, а банки, відповідно, - перед інвесторами. У разі невиконання позичальниками своїх зобов'язань банки звертають стягнення на обтяжене іпотекою нерухоме майно і таким чином виконують зобов'язання перед інвесторами, що обумовлює високу надійність іпотечних цінних паперів. Так працює «вічний двигун іпотеки».

Отже, характерною рисою першої моделі іпотечного рефінансування є їі відносна простота; тут застосовуються такі механізми та інструменти, які відпрацьовувалися протягом століть і переконливо довели свою ефективність та надійність.

Очевидно, що самостійне рефінансування банків шляхом емісії іпотечних цінних паперів є проблематичним у зв'язку із труднощами, які виникають при формуванні пулів іпотек, достатніх для такої емісії.

Участь невеликих банків у іпотечному рефінансуванні стає можливою в разі застосування дворівневих (другої та третьої) моделей. Сутність цих моделей така: на первинному ринку іпотеки універсальні чи спеціалізовані банки надають позичальникам кредити під заставу нерухомості. У разі стандартизації таких кредитів та за наявності відповідної угоди велика фінансова установа, яка має високий рейтинг, бере в заставу або купує іпотеки і на цій підставі емітує іпотечні цінні папери.

Таким чином, завдяки установі посереднику (іпотечній установі II рівня) банки іпотечні кредитори позбавлені необхідності самостійно емітувати іпотечні цінні папери, що підвищує мобільність моделі, але разом з тим робить її складнішою.

За такої моделі рефінансування банки, які надають роздрібні іпотечні кредити на первинному ринку, кредитуються іпотечною установою II рівня під заставу іпотечних 
активів, які їм належать.

Кредитні ризики при цьому залишаються в банків - партнерів іпотечної установи, а залучення коштів ця установа (так званий ломбард для кредиторів) здійснює шляхом емісії іпотечних боргових зобов'язань. У такий спосіб рефінансуються банки США 3 кредитування житлового будівництва та іпотечні установи Франції, Малайзії і Йорданії.

Третя модель іпотечного рефінансування, як і друга, є дворівневою, але має суттєві особливості.

Третя модель створена та реалізована в США і тому називається американською. Сутність їі така: банки, які надають іпотечні кредити і набувають відповідного права вимоги, продають ці кредити, об'єднанні в однорідні пули, іпотечні установи 2-го рівня (так званій установі американського типу) і в такий спосіб рефінансуються. При цьому банки - партнери установи відповідного до угод з нею продовжують обслуговувати продані кредити до повного виконання позичальником своїх зобов'язань.

Порівняльний аналіз різних моделей іпотечного рефінансування виявив їх спільні риси, а також особливості, притаманні тій чи іншій моделі. Він показав, що перша модель $\epsilon$ найпростішою, а друга i, особливо, третя - мобільнішими, але й складнішими порівняно з першою.

Можливість вибору дає змогу застосувати таку модель, яка є ефективнішою за тих чи інших обставин. При цьому різні моделі можуть співіснувати. Наприклад у США поряд із дворівневими моделями (другою і третьою) практикується й перша, за якою деякі великі банки рефінансуються самостійно, не звертаючись до послуг посередників.

Дуже важливою $\epsilon$ порівняльна характеристика різних моделей іпотечного рефінансування за їх ризиковістю, що особливо актуально у зв'язку зі світовою іпотечною кризою 2008 р. та останніми подіями в світі.

Фахівці Центру наукових досліджень НБУ провели аналіз розподілу ризиків між учасниками іпотечного ринку для першої та третьої моделей.

\section{Розподіл ризиків між учасниками іпотечного ринку (однорівненва модель)}

Таблиия 1

Table 1

The risk allocation between mortgage market participants (one-tier model)

\begin{tabular}{|l|c|c|c|}
\hline \multirow{2}{*}{\multicolumn{1}{c|}{ Вид ризику }} & \multicolumn{3}{c|}{ Учасники } \\
\cline { 2 - 4 } & кредитор & позичальник & інвестор \\
\hline Кредитний & $*$ & & $*$ \\
\hline Ринковий & $*$ & $*$ & $*$ \\
\hline Процентний & $*$ & $*$ & $*$ \\
\hline Ліквідності & $*$ & & $*$ \\
\hline Валютний & $*$ & & \\
\hline $\begin{array}{l}\text { Операційно- } \\
\text { технологічний }\end{array}$ & $*$ & $*$ & $*$ \\
\hline Репутації & $*$ & & \\
\hline Юридичний & $*$ & & \\
\hline
\end{tabular}

Джерело: [7]

За однорівненвої моделі діяльність банків-кредиторів повязана з усім спектром ризиків. Ситуація змінюється у разі застосування дворівневої (третьої) моделі іпотечного рефінансування. 
Актуальні проблеми розвитку економіки регіону. Вип 16. T.2

Розподіл ризиків між учасниками іпотечного ринку (дворівненва модель)

Таблиия 2

Table 2

Risk allocation between mortgage market participants (two-tier model)

\begin{tabular}{|c|c|c|c|c|}
\hline \multirow[b]{2}{*}{ Вид ризику } & & \multicolumn{3}{|c|}{ Учасники } \\
\hline & кредитор & позичальник & $\begin{array}{c}\text { емітент } \\
\text { іпотечних } \\
\text { ЦП }\end{array}$ & інвестор \\
\hline 1 & 2 & 3 & 4 & 5 \\
\hline Кредитний & & & * & $*$ \\
\hline Ринковий & & & $*$ & \\
\hline Процентний & $*$ & * & $*$ & $*$ \\
\hline Ліквідності & & & $*$ & $*$ \\
\hline Валютний & & * & $*$ & $*$ \\
\hline $\begin{array}{l}\text { Операційно- } \\
\text { технологічний }\end{array}$ & & & * & \\
\hline Репутації & & & $*$ & \\
\hline Юридичний & & * & * & * \\
\hline
\end{tabular}

Джерело: [7]

Розподіл ризиків ринку за дворівневою (третьої) моделі рефінансування свідчить про те, що більша їх частина переходить від кредитора до емітента цінних паперів. Ризики, властиві діяльності інших учасників залишаються незмінними.

Отже за будь якої моделі іпотечного рефінансування найризикованішою $\epsilon$ діяльність емітента цінних паперів. За однорівневої моделі - це банк-кредитор, за дворівневої - іпотечна установа 2-го рівня. Саме їм притаманний увесь спектр іпотечних ризиків.

Певні ризики несе інвестор. Кредитний ризик власника іпотечного цінного папера за своєю природою такий самий, як і кредитний ризик банку, що надає іпотечні кредити.

За одрорівневої моделі цей ризик пов'язаний 3 можливою неспроможністю первинного позичальника виконувати свої кредитні зобов'язання та/або втратою ліквідності банком-емітентом; за дворівневої моделі до названих ризиків додається ризик можливої втрати ліквідності іпотечною установою 2-го рівня.

Мінімізація кредитного ризику власників іпотечних цінних паперів досягається у pazi:

- об'єктивної оцінки кредитоспроможності позичальника на первинному ринку;

- обережної і виваженої грошової оцінки нерухомого майна;

- суворого контролю (у тому числі з боку наглядових органів) за обсягами емісії іпотечних цінних паперів та достатністю їх покриття;

- першочергового спрямування доходів від іпотечного кредитування на виконання зобов'язань за іпотечними цінними паперами.

Ризик ліквідності для власника іпотечного папера визначається якістю цього папера та ліквідністю фондового ринку.

Мінімізація ризику ліквідності цінного папера досягається за наявності тих самим умов, що мінімізують кредитний ризик. Мінімізація ризику ліквідності фондового ринку досягається у разі його достатнього розвитку.

Решта ризиків інвестора (процентний, валютний та юридичний) нічим не 
відрізняються від таких самих ризиків банку-кредитора.

Міжнародний досвід свідчить, що найефективнішою і найпридатнішою системою для трансформації до існуючих українських реалій $є$ паралельне співіснування двох моделей (одно- та дворівневої) функціонування ринку іпотечного кредитування. Ця модель передбачає наявність первинного та вторинного ринків іпотечного кредитування. Юридично це закріплено в Законі України «Про іпотеку». Первинний ринок характеризується відносинами щодо надання та погашення іпотечних кредитів у площині «іпотечний кредитор - позичальник» [5]. Суть функціонування вторинного ринку полягає у рефінансуванні діяльності іпотечних кредиторів на первинному ринку шляхом емісії іпотечних цінних паперів, продажу іпотечних активів спеціалізованим іпотечним установам або передачі цих іпотечних активів у заставу для залучення кредитів рефінансування [3]. Але економічні обставини як держав, так і фізичних осіб, можуть радикально змінюватися протягом дії іпотечного договору (7-30 років), що суттєво буде впливати на спроможність повернення коштів (кредитний ризик), а також надійність та стабільність фінансової установи зокрема та фінансової системи взагалі, і власне держави. [5].

Висновки. У світовій практиці є три основні моделі іпотечного рефінансування, кожна 3 яких поряд зі спільними для всіх моделей рисами, має специфічні, притаманні лише ій ознаки. Найдавнішою i, мабуть, найнадійнішою є так звана однорівнева, модель, поширена в європейських та багатьох інших країнах світу. Дворівневі моделі, поширені у США та деяких азійських країнах, а також, до певної міри, у Франції, $\epsilon$ мобільнішими порівняно 3 першою, але й більш ризиковими. Дослідження ризиків, пов'язаних із функціонуванням тієї чи іншої моделі, є дуже актуальним, а тому заслуговує на значну увагу науковців та практиків.

Важливим завданням, особливо у країнах, з нестабільною банківської системою, $\epsilon$ розробка такого механізму іпотеки, за якого повернення кредиту є доступним, а також захищає кредитора та особу, що надає кошти, тобто інвестора, тому найефективнішою і найпридатнішою системою для трансформації до існуючих українських реалій $\epsilon$ паралельне співіснування двох моделей (одно- та дворівневої) функціонування ринку іпотечного кредитування. Таким чином розв'язується дилема: як ефективно і безпечно для всіх учасників кредитного ринку використати надані можливості моделей рефінансування в умовах фінансово-економічної кризи, що має призвести до стабілізації банківської системи України.

1. Реверчук С.К., Ковалюк А.О., Яворська Т.В. та ін. Управління реструктуризацією фінансових посередників в економіці України. Львів: В-во «Растр-7», 2011. 280 с.

2. Рефинансирование. URL: http://delo.ua/wiki/refinansirovanie-111017 (дата звернення 09.11.2020).

3. Москвічова О.С. Рефінансування як одна з форм державного регулювання ринку кредитних послуг. Наукові записки. Серія «Економіка»: збірник наукових праць. Острог: Видавництво НУ «Острозька академія», 2013. Випуск 23. с. 310-314.

4. Указ Президента України «Про додаткові заходи щзодо подолання фінансової кризи в Україні» від 17.11.2008 №1046. URL: http://zakon4.rada.gov.ua/laws/show/1046/2008 (дата звернення 09.11.2020).

5. Гордіца Т. М. Шляхи мінімізації іпотечного кредитного ризику банківських установ в умовах світової фінансової кризи. Регіональна економіка, 2009. № 1. С. 147-155. URL: http://nbuv.gov.ua/UJRN/regek_2009_1_20 (дата звернення 09.11.2020).

6. Закон України «Про іпотеку» від 05.06.2003 №898-IV URL: http://zakon2.rada.gov.ua/laws/ show/898-4 (дата звернення 09.11.2020).

7. Грищук Н., Крилова В., Набок Р., Незнамова А., Шитко О. Іпотечне кредитування: проблеми та перспективи розвитку в Україні. Інформаційно-аналітичні матеріали. К.: Центр наукових досліджень НБУ, 2004. 88 с.

\section{References}


Актуальні проблеми розвитку економіки регіону. Вип 16. T.2

1. Reverchuk, S.K., Kovaliuk, A.O., Yavorska, T.V., et.al. Management of restructuring of financial intermediaries in the economy of Ukraine. Rastr-7, 2011.

2. ERefinancing.E Delo, delo.ua/wiki/refinansirovanie-111017. Accessed 09 Nov. 2020.

3. Moskvichova, O.S. "Refinancing as one of the forms of state regulation of the credit services market". Proceedings. Series "Economics": a collection of scientific papers, vol. 23, 2013, pp. 310-314.

4. "On additional measures to overcome the financial crisis in Ukraine. The Decree of the President of Ukraine" Verkhovna Rada of Ukraine, zakon4.rada.gov.ua/laws/show/1046/2008. Accessed 09 Nov. 2020.

5. Horditsa, T. M. "Ways to minimize the mortgage credit risk of banking institutions in the global financial crisis". Regional economy, no 1, 2009, pp. 147-155. Vernadsky National Library, nbuv.gov.ua/UJRN/regek_2009_1_20. Accessed 09 Nov. 2020.

6. “About the mortgage. The Law of Ukraine.” Verkhovna Rada of Ukraine, zakon2.rada.gov.ua/laws/ show/898-4. Accessed 09 Nov. 2020.

7. Hryshchuk, N., Krylova, V., Nabok, R., Neznamova, A., and O. Shytko "Mortgage lending: problems and prospects for development in Ukraine.” Information and analytical materials, NBU, 2004. 